\title{
Water management, migration and governance
}

Regions $\mathcal{E}$ Cohesion aims to foster dialogue on the human and environmental impacts of regional integration processes. The mission of the journal is purposely defined broadly so as to create as wide an inter-regional dialogue as possible on issues affecting communities throughout the world. As the introduction to the first issue of volume one clearly stated, our goal is move people rather than territories to the center of debates on regional integration.

Having said this, certain themes have been recurring in the articles that we have been privileged to publish: environmental rights, migration, public health, vulnerability, etc. As editors, it is important for us to recognize these links between the analytical pieces that we are publishing, both as scientific articles and normative analyses in the "Leadership Forum," in order to identify the agenda that is emerging from our open call for contributions and examine the character that the journal is taking. We are of course, grateful to have received interesting articles from both young and established scholars as well as thought-provoking contributions from experienced practitioners. We are very appreciative that many colleagues have understood the spirit of our call and they have responded with manuscripts that contribute to the establishment of a coherent intellectual vision that includes both scientific and normative elements. In fact, this issue of Regions and Cohesion builds upon themes that were prominent in the journal's first volume (2011), namely 1) the management of environmental resources (specifically water), 2) cohesion and migration/migrant groups, and 3) the intersection of governance and cohesion, which is examined in the leadership forum and the book reviews.

\section{Water management in North America}

Why in the 21st century do we still need to talk about water management? We would like to imagine that all our readers have safe access to 
potable water and sanitation facilities. But as far as the dramatic trends related to water stress (also called "water crisis") around the globe are concerned, they still affect about 780 million people (World Health Organization, 2012). For this reason, there will always be space and interest in this journal to talk about water management issues. This was a topic that was addressed by some authors in Regions \& Cohesion 1(3), a special issue on "Environment and Natural Resources Governance: Rethinking PublicPrivate Relationships."

We do not want to dismiss the water and sanitation efforts outlined in the Millennium Development Goals which aim to reduce the statistic cited above that recognizes the fact that one in five people in developing countries have no access to drinking water, and the fact that approximately 2.5 billion people (about half the population in developing countries) have no access to an adequate sanitation device (World Health Organization, 2012). However, it is generally accepted that these goals remain far away as we approach the 2015 deadline originally set to meet them. Also, the increasing number of recent international fora (such as the 2011 UN Climate Change Conference in Durban and the United Nations Conference on Sustainable Development to be held in Rio de Janeiro in June, 2012 (Rio $+20)$ ), while they ground global debates on access to water resources (and the human right to water) for all populations in broader sustainable development agendas, their presence and repetition demonstrates the lack of real progress achieved towards the attainment of these objectives. This is highlighted in this issue of Regions $\mathcal{E}$ Cohesion in our special section entitled "Letters to Leaders," in which we are pleased to receive and publish the standing position of Caritas Luxembourg on the Zero Draft document to be analyzed as the main policy outcome at Rio +20 . We thank our colleague Norry Schneider for his role in the formulation and publication of this document. This proposal is part of a Caritas Luxembourg position paper sent to the Luxembourg Ministry for sustainable development and infrastructure in order to inform Luxembourg's government position on sustainable development in advance of the Rio +20 conference.

While water has received prominent attention in these international debates, it is not, however, only a global issue. Existing regional disparities in terms of water needs, water supplies, and government structures, make universal solutions nearly impossible. As James Wescoat and Sarah Halvorson (2012), state: "Water governance at the regional scale reflects complex interactions and insecurities involving diverse riparians, hydrostrategic agendas, ideological dynamics, biophysical complexities, and often competing visions of basin boundaries" (p. 86). Indeed, water has no boundaries.

For about four decades, many water scholars have analyzed the role of water in cross-border regions as a source of dispute and even conflict be- 
tween uses and users (among a large list: Bennett \& Herzog, 2000; Blatter \& Ingram, 2001). Cross-border water management is a challenge in many world regions and the literature in this field is diverse. Many authors focus on legal frameworks and the intersection of governance, rights and economic interests (such as Daibes-Murad, 2005; Gopalakrishnan, Tortajada, and Biswas, 2005). Others focus on local power relationships and the roles local authorities play, both formally and informally, in negotiating water distribution (see Maganda, 2005; Walsh, 2008). Finally, numerous studies discuss regional water management with a focus on regional institutional frameworks and supranational agreements in the field of water management (see Mumme, 2003; Ingram, Laney, \& Gillilan, 1995).

In this issue of Regions $\mathcal{E}$ Cohesion, we are proud to present three chapters contributing to this productive academic debate on cross-border water issues. The first focuses on international cooperation for water management along the U.S.-Mexico border: Stephen Mumme, Oscar Ibáñez and Suzanne M. Till analyze the state of binational multi-level water governance in this border region. The article's originality lies in the application of a conceptual approach (multilevel governance) generally utilized in analyses of European cases to a study of North American border regions. The authors study institutions/agents with the objective of identifying mechanisms for the facilitation of greater binational cooperation in managing internationally shared water resources along the U.S.-Mexico border. They point to some good examples of transboundary institutions which have contributed to the resolution of recent water conflicts along the two international rivers, the Rio Grande and the Colorado, that cross the US-Mexico border.

The second article is also related to this border. Alfonso Cortez-Lara focuses on two recent conflicts between transboundary water-stakeholders linked to a salinity problem and the paving of the All-American Canal. The negative consequences, particularly for farmers in the Mexicali Valley, offer lessons on how water conflicts can negatively affect social cohesion in the U.S.-Mexico border region.

Finally the third article on water in this issue addresses water management across domestic borders in the United States (US). Laurel Saito, Kayla Berry, Derek Kauneckis, and Kate Berry provide an original comparative research project on the perceptions of successful cooperation on water quality issues across six western US interstate watersheds (rivers passing through jurisdictional boundaries of two or more states) studied in this region which face particular water problems concerning over-allocation and overuse. They are also often water quality-impaired. This article analyzes the mechanisms of cooperation used to manage water quality across these watersheds as well as related perceptions of success, thus 
offering insights into regional cooperation and social cohesion related to shared environmental resources.

\section{Social cohesion and migration}

Obviously there are many approaches to the study of social cohesion and many specific issues related to this concept. Regions $\mathcal{E}$ Cohesion has already published articles related to cohesion and migration, both forced and voluntary. In Volume 1 (2) we published a study by Marcela Ceballos on policies related to displaced persons in the Colombia-Ecuador border region and how these positions have affected both asylum seekers and the relationship between these two states. In Volume 2 (1), we presented an article by Kazuko Suzuki on Korean immigrants in Japan and the United States that studied forms of adaptation and how they differed between the two countries.

This issue also includes an article that relates to these themes. Takeyuki Tsuda examines the Japanese American diaspora and the lack of a Nikkei identity. He studies the experiences of this group, which became assimilated in the United States over generations, and he argues that it no longer maintains a notable diasporic identification with an ethnic homeland or with other generations of Japanese migrants present in the Americas. Like Suzuki, he contends that cultural similarities are not the primary factor affecting cohesion in/around ethnic communities.

\section{Cohesion and governance}

What affects institutional performance and how does this in turn impact social cohesion? The lead article in the Leadership Forum tackles this issue from the very important perspective of intergovernmental relations. We are honored to publish the Keynote Address from the 2011 Conference of the Consortium for Comparative Research on Regional Integration and Social Cohesion (RISC), held in Rustenburg South Africa on the theme "Social Cohesion: The Missing Link to Regional Integration?" which was organized by the Department of Politics at the University of Johannesburg. The Keynote Speaker, Ambassador Dumisani S. Kumalo, is CEO of the Thabo Mbeki Foundation and Former Permanent Representative of South Africa to the United Nations. His comments are thought-provoking as he discusses the history of the establishment of "African Cohesion" and the challenges posed by the lack of "international cohesion," which Ambassador Kumalo identifies as a necessity for regional cohesion to emerge 
without external interference. His speech tackles important issues related to 2011 events, such as the political crises in Côte d'Ivoire and Libya as well as the violent split of Sudan.

The book reviews included in this issue also tackle the relationship between cohesion and governance. In his essay entitled, "The Elusive Quest? African Regionalism, Social Cohesion, and Institutions," Robert Compton examines African development with particular focus on social cohesion and national integration. He contends in his review of four seminal works that "the political and economic benefits of coordinated social cohesion and regional integration compelled countries to cooperate with one another to establish common policies and behavioral norms." Compton also studies the implications of state-society relations for the establishment of cohesion. This is a central theme of the book Perspectivas Comparativas del Liderazgo/Comparative Perspectives on Leadership, reviewed in this issue by Amaya Querejazu.

During this, its second year, Regions \& Cohesion continues to focus on people and communities as the heart of regional integration debates. As always, we are grateful to the authors who have contributed to this issue.

The Editors

\section{References}

Blatter, J. \& Ingram, H. (Eds.). (2001). Reflections on water: New approaches to transboundary conflicts and cooperation. Cambridge, MA: The MIT Press.

Bennett, V. \& Herzog L. (2000). U.S.-Mexico borderland water conflicts and institutional change: A commentary. Natural Resources Journal, 40, 73-988.

Daibes-Murad, F. (2005). A new legal framework for managing the world's shared groundwaters: A case study from the Middle East. London : IWA Publishing.

Gopalakrishnan, C., Tortajada, C., \& Biswas, A., (Eds.). (2005). Water institutions: Policies, performance and prospects. New York : Springer.

Ingram, H.; Laney, Gillilan, (1995). Divided waters: Bridging the U.S.-Mexico border. Tuscon, AZ: The University of Arizona Press.

Maganda, C. (2005). Collateral Damage: How the San Diego-Imperial Valley Water Agreement affects the Mexican side of the border. Journal of Environment and Development, 14, 486-506.

Mumme, S. (2003). Revising the 1944 water treaty: reflections on the Rio Grande drought crises and other matters. Journal of the Southwest, 45, 649-670.

Walsh, C. (2008). Building the Borderlands: A transnational history of irrigated cotton on the Mexico-Texas border. College Station: Texas A\&M University Press.

Wescoat, J., \& Halvorson, S. (2012). Emerging regional perspectives on water research and management: An introductory comment. Eurasian Geography and Economics, 53, 87-94.

World Health Organization and UNICEF. (2012). Progress on drinking water and sanitation. 2012 update. New York: United Nations. 